\title{
РУССКИЙ И ТЮРКСКИЕ ЯЗЫКИ: БИЛИНГВИЗМ И ПОЛИЛИНГВИЗМ
}

\author{
RUSSIAN AND THE TURKIC LANGUAGES: \\ BILINGUALISM AND MULTILINGUALISM
}

\author{
МАХАНБЕТ ДЖУСУПОВ
}

\begin{abstract}
The paper focuses on the issue of contact between Russian and the Turkic Languages in Central Asia with regard to bilingualism and multilingualism. In the Central Asian Republics Russian is the second or third most frequently used language. For the last twenty years the number of bilingual and multilingual speakers who use Russian has been decreasing. This fact is primarily related to the new sociolinguistic situation in the Central Asian Republics.
\end{abstract}

Маханбет Джусупов, Узбекский государственный университет мировых языков, Ташкент - Узбекистан.

Функционирование одного языка в географическом пространстве, где уже есть сформировавшаяся речевая среда на другом языке, обязательно будет сопровождаться их контактированием ${ }^{1}$. Контактирование осуществляется не только на уровне языков, (например, казахского и русского), но и на уровне национальных миров, вбирая в себя взаимовлияние и взаимопроникновение как языков, так и культур, литератур, обычаев, традиций, образовательных стандартов и т.д.

Итак, формирование би- и полилингвизма - это больше, чем собственно лингвистическое явление. Поэтому в данном случае следует

${ }^{1}$ Большой энизиклопедический словарь. Языкознание, Москва 2000, с. 237; У. В а й нр а й х, Одноязычие и многоязычие, „Новое в лингвистике”, Москва 1972, вып. VI, с. 25-60; его же, Языковые контакты: состояние и перспективы исследования, Киев 1979; В.Ю. Р о з е н ц в е й г, Языковые контакты, Ленинград 1972; Э. Х а у г е н, Языковой контакт, „Новое в лингвистике”, Москва 1972, вып. VI, с. 61-80; Е.А. К а р л и н с к и й, Основы теории взаимодействия языков, Алма-Ата 1990; М. Д ж у с у п о в, Збуковые системы русского и казахского языков. Слог. Интерференция. Обучение произномению, Ташкент 1991; его же, Социолингвистические и лингводидактические проблемы языка как средства общения и предмета изучения, [в:] Русистика в СНГ, Санкт-Петербург 2002, с. 64-74; его же, Русская звучащая речь и тюркское фонологическое сито, [в:] Материалы Международной научно-практической конференции „Русский язык в пространстве Центрально-азиатского региона СНГ”, Бишкек 5-10 августа 2007, с. 26-28. 
говорить не только о приходе русского языка в тюркский мир Центральной Азии, но и о приходе в данное полинациональное, полиязыковое географическое пространство и в целом русского мира, то есть мира русского духа, мира русской песни, русского видения и восприятия окружающей действительности.

Таким образом, контактирование языков в процессе формирования вообще би- и полилингвизма, или же новых их типов и видов на территории, в которой уже функционировали би- и полилингвизм, приносит с собой новый национальный мир общения, сообщения и воздействия в том случае, если пришедший новый язык начинает занимать серьезные социальные позиции, функционируя во всех основных социальных сферах деятельности общества (сфера быта, сфера науки, сфера официально-деловых отношений, сфера СМИ, сфера художественной деятельности).

С приходом русского языка в тюркский мир Центральной Азии произошло именно это: вместе с русским языком пришел и русский мир.

Функционирование русского языка на разных географических пространствах бывает контактирующим с другими языками и - неконтактирующим.

В условиях неконтактирования с другими языками русский язык функционирует один, а носители его, как правило, монолингвы. Такие условия использования русского языка его носителями существуют на большей части территории России.

В условиях контактирования с другими языками русский язык функционирует как внутри России (Северный Кавказ, Дагестан, Татарстан, Башкортостан и т.д.), так и за ее пределами. Это, прежде всего, территория СНГ. На этом географическом пространстве русский язык находится в тесном контакте с шестью тюркскими языками, которые являются государственными языками соответствующих тюркоязычных республик (Казахстан, Кыргызстан, Туркменистан, Азербайджан, Узбекистан и Автономная Республика Каракалпакстан).

Из этих шести тюркских республик пять находятся на территории Центральной Азии, где традиционно (уже тысячелетия), еще до прихода сюда русского языка функционировал билингвизм и полилингвизм. Подтверждается это историческими памятниками. Так, например, созданный в XI веке Махмудом Кашгари „Дивани лугат ат-тюрк”, в котором есть ценнейшие сведения о тюрках, о тюркском языке, о его диалектах, о владении частью тюркского населения не только разными тюркскими диалектами, но и языками других народов, и - наоборот.

Другим серьезным письменным памятником, доказывающим функционирование би- и полилингвизма в тюркском мире Центральной 
Азии, является словарь Махмуда Замахшари, который был вначале двуязычным - арабо-персидским, затем трехъязычным - арабо-персидско-тюркским, и наконец - арабо-персидско-тюркско-монгольским. Как правило, би- и полилингвистические словари создаются уже при функционировании этих языков не раздельно, а в совокупности, то есть когда они становятся компонентами би- и полилингвизма. Арабоперсидско-тюркско-монгольский словарь Махмуда Замахшари был создан в конце XI - первой четверти XII веков. Данный словарь в 2008 г. на основе рукописи, хранящейся в музее им. А. Навои в г. Ташкенте, был издан в столице Японии - Токио 2.

Таким образом, русский язык в Центральную Азию пришел не для того, чтобы создавать вообще билингвизм и полилингвизм, а для того, чтобы создавать новые типы би- и полилингвизма: казахско-русский; казахско-узбекско-русский; казахско-киргизско-узбекско-русский; казахско-персидско-арабско-русский; казахско-узбекско-персидско-русский; узбекско-русский; узбекско-казахско-русский; узбекско-казахско-киргизско-русский; узбекско-персидско-казахско-русский; узбекско-персидско-арабско-русский; узбекско-русско-персидский и т.д.

Итак, русский язык пришел в Центральную Азию, в которой уже активно функционировали разные типы би- и полилингвизма. Лингвистическими компонентами этих типов би- и полилингвизма были тюркские языки, фарси (в разновидности дари), арабский язык.

Русский язык в билингвистический и полилингвистический мир Центральной Азии принес славянский лингвистический компонент, а вместе с этим как русскую культуру, так и в целом европейскую культуру.

Функционирование русского языка в тюркском мире Центральной Азии и формирование с его участием типов би- и полилингвизма началось не сразу. Объясняется это тем, что русский язык в Центральную Азию пришел вместе с процессом колонизации ее Царской Россией, поэтому формирование и развитие билингвизма и полилингвизма с его участием в то время было исключительно малопродуктивным, исключительно локализованным, исключительно выборочным (в плане участия в этом процессе представителей местных тюркских народов). Такое положение дел не способствовало формированию би- и полилингвизма с участием русского языка не только как первого или второго компонента, но и даже третьего и четвертого. В то время тюркско-русскими билингвами были, как правило, дети тюркской знати или тюркоязычные дети (казахи, узбеки и т.д.), которых отбирали в специ-

2 The Muqaddimat al-Adad: A Facsimile Reproduction of the Quadrilingual Manuscript (Arabic, Persian, Chagatay and Mongol), Tõkiõ 2008. 
альную школу по подготовке переводчиков, специалистов по делопроизводству. Но таких учащихся было очень и очень мало, т.е. единицы.

Массовое формирование и функционирование тюркско-русского би- и полилингвизма началось после 1917 года, когда большевики объявили равенство народов, а в связи с этим равенство в получении школьного и послешкольного образования.

Пик формирования тюркско-русского би- и полилингвизма пришелся на 50-60-70-80-е годы XX века, то есть на время после Второй мировой войны.

В это время формируется тотальный билингвизм, вторым компонентом которого становится русский язык. Это казахско-русский, узбекско-русский, киргизско-русский, туркменско-русский, каракалпакско-русский и др. типы билингвизма.

Быстрое развитие тюркско-русского билингвизма обеспечивалось осуществлением следующих мероприятий:

1) Тотальное обучение русскому языку во всех типах школ с инофонной (тюркоязычной) аудиторией.

2) Открытие большого количества дошкольных учреждений и школ с русским языком обучения, в которых половина, а может и большее количество учащихся были дети нерусской, неевропейской национальности.

3) Приток большого количества русскоязычных граждан СССР в республики Центральной Азии.

4) В подавляющем большинстве случаев ведение делопроизводства на русском языке.

5) Фактическое выполнение русским языком функций государственного языка, хотя в бывшем СССР не было Закона о государственном языке.

И т.Д.

Такое положение дел способствовало быстрому и массовому формированию тюркско-русского билингвизма от мала до велика. При этом типы тюркско-русского билингвизма (казахско-русский, узбекско-русский и т.д.) стали активно вытеснять тюркско-персидский, тюркско-арабский билингвизм и полилингвизм. Такой билингвизм и полилингвизм (например, казахско-персидско-арабский, узбекско-персидско-арабский) стал постепенно утрачиваться и почти полностью ушел в небытие, за исключением тех индивидов и небольших коллективов, которые занимались историей, исследованием древних текстов и т.п. Эти специалисты были полилингвами с обязательным знанием русского языка (казахско-арабско-русский, казахско-русско-персидский, узбекско-арабско-русский, узбекско-персидско-русский, узбекско-русско-персидский и т.д.). 
При этом почти полностью стал исчезать русско-тюркский билингвизм, который в первые годы советской власти и примерно до 60-х годов XX века имел небольшое по массовости, но функционально достаточно серьезное распространение среди интеллигенции и работников государственной службы. Происходило парадоксальное лингвистическое событие: чем сильней становилось Советское государство, сильным и полифункциональным становился русский язык в Центральной Азии, тем быстрее становился достоянием истории русско-тюркский билингвизм во всех своих разновидностях (русско-казахский, русско-узбекский, русско-киргизский...).

История формирования русско-тюркского билингвизма и полилингвизма, а также тюркско-русского билингвизма и полилингвизма начинается еще до времен Золотой Орды.

Ранние контакты восточных славян с тюркскими племенами, возникшие еще до образования в IX веке Киевской Руси, обусловили практическое знание ими тюркских языков, которое особенно укрепилось ко времени монголо-тат. нашествия в XIII-XV вв. и поддерживалось необходимостью сношений с Золотой Ордой. Появились офиц. переводчики-толмачи с турец., казанско-тат. и крымскотат. языков..., тюрк. слова толковались в азбуковниках... ${ }^{3}$.

Итак, Русь постоянно контактировала с половцами (кыпчаками). В связи с этим среди славянского населения, как уже отмечено выше, было достаточно большое количество людей, владеющих кыпчакским языком, который является основой одного из трех групп тюркских языков (огузский, кыпчакский, карлукский). Самым крупным представителем кыпчакской группы тюркских языков является современный казахский язык.

Золотая Орда в основном говорила на тюркском (кыпчакском) наречии, так как монголы Золотой Орды были тюркизированы не только по языку, но и по культуре, обычаям, традициям. Поэтому в Золотой Орде на Руси был кыпчакско-русский (тюркско-славянский) билингвизм и русско-кыпчакский (славяно-тюркский) билингвизм, которые постепенно уходили в прошлое, что связано, прежде всего, с распадом Золотой Орды как империи, просуществовавшей более трехсот лет.

Возрождение тюркско-славянского (казахско-русского, узбекско-русского и т.д.) и славяно-русского (русско-казахского, русско-узбекского и т.д.) билингвизмов началось со времен колонизации Российской Империей народов Центральной Азии.

Посланцы Российской Империи - миссионеры, военные (офицеры), путешественники, ученые, как правило, владели одним, а то и не-

${ }^{3}$ Большой энциклопедический словарь. Языкознание, Москва 2000, с. 525. 
сколькими тюркскими языками, владели арабской графикой. Дело дошло до того, что в Туркестанском или Семиреченском губернаторстве определенная часть работников владела местным языком (одним из тюркских).

Переселенцы из разных губерний России через некоторое время уже владели одним из тюркских языков. Такое явление было характерно для славян (преимущественно - русских), переселенных в XVIIIXIX веках на территорию Казахстана.

После победы большевиков (1917 г.) многие специалисты, направленные для работы в республики Центральной Азии, или уже владели одним из восточных языков, или же по прибытии сюда быстро овладевали одним из местных тюркских языков. Это значит, что „послеоктябрьская интеллигенция", работавшая в республиках Центральной Азии, в основном была русско-тюркско билингвальной.

Все эти достижения русского языка как первого компонента в русско-тюркском билингвизме почти полностью нейтрализовались (исчезли) в 60-70-80-е годы XX века.

После распада СССР и плавного формирования СНГ начался отток русскоязычного населения из бывших союзных республик, что способствовало существенному уменьшению естественной русскоязычной среды и снижению частоты использования русского языка практически во всех сферах социальной деятельности индивида.

Почти во всех сферах социальной деятельности человека стал доминировать государственный язык (узбекский, туркменский, ...). В некоторых социальных сферах государственный язык и русский язык стали функционировать на равных правах (например, в научной сфере, в сфере средств массовой информации).

Русский язык в школе и в вузе сохранил свой статус - статус обязательной общеобразовательной дисциплины. Уменьшились часы на дисциплину „Русский язык” в школе и в вузе. Незначительно увеличились часы на преподавание английского языка. Начался настоящий бум по изучению английского языка (частные уроки, курсы и т.д.).

Все это (и кое-что другое) способствовало снижению уровня владения русским языком школьниками и студентами вузов, а это значит, что стало уменьшаться число людей носителей тюркско-русского (узбекско-русского, туркменско-русского, ...) билингвизма ${ }^{4}$. Казахстан в этом вопросе стоит несколько особняком. В Казахстане этот процесс

4 Об уровне знания русского языка узбекистанцами см. подробно: О.Б. А т а - М и р з а е в, Русский язык в жизни узбекистанцев, [в:] Нужен ми русский язык новым независимым государствам. Материалы Международной конференции, Москва 29 февраля 2008, с. 59-61. 
гораздо меньше заметен, чем в других тюркоязычных государствах Центральной Азии 5 .

Как обстоит дело в этих республиках с русско-тюркским билингвизмом после распада СССР? Во всех республиках Центральной Азии после распада СССР русско-тюркский (русско-узбекский, русско-казахский, русско-кыргызский) билингвизм начал переживать второе рождение, но не в таких объемах и не совсем в такой форме, которые его характеризовали в период существования СССР.

В Узбекистане в настоящее время среди русскоязычных студентов высших учебных заведений практически нет совсем не владеющих узбекским языком. Почти все понимают элементарную узбекскую речь (в транспорте, на рынке, в магазине и т.д.).

Многие из них владеют узбекским языком на уровне понимания звучащей речи, но свободно говорить, писать на узбекском языке не могут. Но почти все русскоязычные студенты смогут написать заявление на узбекском языке, если есть образец, в котором нужно поменять только фамилию, имя и т.п. Определенная часть русскоязычных студентов очень хорошо владеет узбекским языком на уровне устной речи.

Русскоязычных студентов высших учебных заведений, хорошо владеющих узбекским языком на уровне всех четырех видов речевой деятельности, немного.

И, тем не менее, следует отметить, что на уровне пассивного билингвизма (понимания и элементарного участия в речевом процессе) многие русскоязычные студенты вузов Узбекистана узбекским языком владеют.

В Казахстане в период перестройки и после распада СССР, где-то до 1995-1996 гг., русско-казахский билингвизм начал развиваться более активно, чем в предыдущие годы. Русскоязычные индивиды неказахской национальности, русскоязычные трудовые коллективы достаточно серьезно начали изучать казахский язык, учиться делопроизводству на казахском языке. Русскоязычные казахи начали возвращаться в генетическое лингвистическое родовое гнездо, они начали наполняться содержанием настоящего активного билингвизма, то есть казалось, что все идет к тому, что русско-казахский билингвизм поднимается на достаточно хорошую высоту, хотя, конечно же, не достигнет высоты казахско-русского билингвизма. Таким образом, контактирование русского языка с казахским языком начало приобретать мобильный двусторонний характер, то есть межъязыковые (русско-казахские) контакты ста-

5 Об особенностях функционирования русского языка в настоящее время в странах СНГ см. подробно: Русистика в СНГ, Санкт-Петербург 2002. 
ли происходить не только в сознании казаха, но и в сознании русского (или же русскоязычного человека, социума).

Однако примерно в 1996-1997 гг. этот процесс пошел на спад. Причин много: 1) Парламент Казахстана в основном работает на русском языке; 2) Публичные выступления многих руководителей ведомств, министерств и т.Д. осуществлялись на русском языке (или в их выступлениях отводилось гораздо больше времени для речи на русском языке, чем для речи на казахском языке); 3) Делопроизводство на местах (сверху донизу и снизу доверху) продолжало осуществляться (как в советское время) на русском языке, потому что не была подготовлена ни материальная, ни кадровая база; 4) В составе государственных служащих (от акиматов до министерств и далее) уже была сформирована целая плеяда генетических казахов, не владеющих или слабо владеющих казахским языком как родным и как государственным, которые получили школьное и вузовское образование в советское время и только на русском языке; 5) Откровенное игнорирование казахского (государственного) языка определенной частью государственных служащих высших и низших рангов: их стойкое нежелание вести делопроизводство и в целом служебную деятельность на казахском языке.

В настоящее время принимаются серьезные меры для расширения социальных функций казахского языка и, следовательно, для повышения уровня русско-казахского билингвизма (выделение финансов, издание словарей, учебников, учебных пособий, открытие учебных курсов и т.Д.).

Время покажет, что из этого получится. Мы думаем, что со временем положительные результаты будут, и контактирование русского языка с казахским языком в сознании граждан Казахстана, в настоящее время не владеющих казахским языком, будет активным, речепродуктивным, на более серьезном уровне социально запрашиваемым.

Процесс контактирования тюркских языков с русским языком в советское время породил много вопросов как собственно лингвистического, так и образовательного характера, которые стали социальными проблемами, их решением занимались научно-исследовательские институты, центры, кафедры при университетах и институтах, государственные и партийные органы.

Одной из таких серьезных проблем была проблема создания эффективной методики обучения русскому языку с учетом условий каждого конкретного национального контингента (казахского, узбекского, кыргызского, ...).

Эта проблема возникла в связи с тем, что любой неродный язык овладевается не сразу: с большим трудом, т.е. с порождением большого количества языковых и речевых ошибок. Эта интерференция появ- 
ляется не только в результате того, что в изучаемом (русском) и родном (казахском, узбекском и т.д.) языках больше различий, чем сходств, но и в связи с наличием исторических особенностей в традициях и обычаях и в целом в культуре каждого тюркского народа, находящегося в контакте с русским народом, с русскоязычным населением.

Таким образом, процесс овладения русским языком тюркскими народами Центральной Азии сопровождался языковой и речевой интерференцией, преодоление (или нейтрализация) которой была одной из главных задач специалистов в области русской лингводидактики и методики обучения русскому языку в инофонной (в нашем случае тюркофонной) аудитории.

В целях распространения русского языка в бывшем СССР осуществлялись широкомасштабные, научно обоснованные, профессионально-направленные, национально-ориентированные, географически неограниченные мероприятия; эти мероприятия с точки зрения дидактики, психологии, советской идеологии, лингводидактики и методики были исключительно выверенными. С позиции сегодняшнего дня их смело можно назвать безукоризненными в смысле как точечной, так и массовой направленности на широкое и глубокое внедрение русского языка в полиинофонную аудиторию.

Все эти мероприятия образовательного, культурологического, идеологического и т.д. характера имели одностороннюю направленность - формирование инофонно-русского билингвизма, то есть билингвами становились, как правило, негенетические носители русского языка. Вопрос о формировании русско-инофонного билингвизма не ставился, а если ставился, то декларативно. Именно это обстоятельство стало базисной основой для повсеместного тотального формирования инофонно-русского (в нашем случае тюркско-русского) билингвизма и полилингвизма, но - не русско-инофонного.

Итак, билингвизм и полилингвизм в тюркоязычных странах Центральной Азии - результат контактирования языков, в том числе и русского языка.

Функционирование би- и полилингвизма в тюркском мире Центральной Азии имеет многовековую историю. Типы и виды би- и полилингвизма менялись, но при этом, как правило, обогащались новыми компонентами (языками). Многовековая история би- и полилингвизма в Центральной Азии убеждает нас в том, что тюркские языки всегда были первым компонентом устного мультилингвизма на своей территории. В период же прихода арабского языка и фарси в качестве компонентов двуязычия и многоязычия в письменной речи тюркские языки не были первым компонентом соответствующих типов и видов бии полилингвизма. 
В XX веке контактирование русского языка со всеми тюркскими языками было исключительно плодотворным как в плане собственно языковом, так и в плане общеобразовательном, культурологическом, научном. Этот процесс был двусторонним с доминированием влияния русского языка на тюркские языки. 